\title{
Effect of Different Cavity Disinfectants on Marginal Sealing Ability of a Seventh-generation Dentin Bonding Agent: An In Vitro Study
}

Nitin M Lokhande ${ }^{1}$, Sushilamma H Manjunath ${ }^{2}$, Ashishkumar K Patil ${ }^{3}$, Priyanka D Bawa ${ }^{4}$, Rohini Mahajan ${ }^{5}$, Harsha Mahajan $^{6}$

\begin{abstract}
Aim: To determine the effect of three different cavity disinfectants ( $2 \%$ chlorhexidine gluconate, $2.5 \%$ sodium hypochlorite, and $2 \%$ iodine solution) on microleakage in a seventh-generation dentin-bonding system.

Materials and methods: Class V cavity was prepared on 50 extracted molars $(n=50)$. The respective experimental groups were treated with cavity disinfectants and Adper Easy One Bond. Preparations without cavity disinfectants worked as negative control and those with neither disinfectant nor dentin-bonding resin application worked as positive controls. After the cavity preparations were restored with resin composite $\left(\right.$ Filtek $^{\text {TM }} \mathrm{Z} 350$ ), the teeth were then subjected to dye leakage tests. Microleakage was assessed for both occlusal and gingival margins, using a stereomicroscope. Data were analyzed using (ANOVA; Kruskal-Wallis) test.

Results: No statistically significant differences were observed among $2 \%$ chlorhexidine gluconate, $2.5 \%$ sodium hypochlorite, and $2 \%$ iodine and also no statistically significant differences were observed between occlusal and gingival margins of groups.

Conclusion: (1) $2 \%$ chlorhexidine gluconate, $2.5 \%$ sodium hypochlorite, and $2 \%$ iodine produced significantly higher microleakage when used with seventh-generation dentin-bonding agent. (2) $2 \%$ chlorhexidine gluconate produced lesser microleakage in comparison with $2.5 \%$ sodium hypochlorite and $2 \%$ iodine. (3) The gingival margins exhibited greater microleakage than occlusal margins.

Clinical significance: The application of cavity disinfectants on prepared tooth before the application of dentin-bonding agent could help to reduce the potential risk of residual caries and postoperative sensitivity.

Keywords: Cavity disinfectants, Chlorhexidine gluconate, lodine, microleakage, Seventh-generation dentin-bonding agent and sodium hypochlorite.

The Journal of Contemporary Dental Practice (2020): 10.5005/jp-journals-10024-2772
\end{abstract}

\section{INTRODUCTION}

The ultimate goal of operative dentistry is to restore the tooth to regain its form and function. One of the requisites of a restorative material is to adapt itself to cavity walls, but currently none of the material actually adheres chemically with the cavity walls. ${ }^{1}$

Bonding between the composite and tooth is micromechanical which also strengthens the tooth structure. ${ }^{1}$ Polymerization shrinkage during the setting of composite resin happens to occur with contraction gap at tooth restoration margins. ${ }^{2}$ The bacteria from oral cavity enter the contraction gaps produced by the polymerization shrinkage of composite resins. ${ }^{3}$ The microleakage is the most common problem associated with all restorative materials. Microleakage can be enhanced by incomplete mechanical removal of infected dentin followed by inappropriate disinfection of prepared cavity. Although the restoration is well sealed from oral cavity, the remaining bacteria from the smear layer have been found to proliferate beneath the restoration, creating a potential problem in restorative dentistry. ${ }^{3}$

The problems of secondary caries, hypersensitivity, and pulpal pathosis have been revealed to be associated with microleakage and residual bacteria under restoration. ${ }^{4}$ The importance of dentin disinfection before the placement of restoration was also well-documented. ${ }^{5}$ Many investigators have advocated the use of caries-disclosing dyes for recognition of carious dentin. ${ }^{3}$ It has also been reported that the microorganisms present in smear layer cannot be completely cleared away by the action of restorative materials containing disinfecting agents. ${ }^{6}$ A number of antibacterial
1,3,5 Department of Conservative Dentistry and Endodontics, SMBT Dental College and Hospital, Sangamner, Maharashtra, India

${ }^{2}$ Department of Periodontics, SMBT Dental College and Hospital, Sangamner, Maharashtra, India

${ }^{4}$ Department of Conservative Dentistry and Endodontics, Pandit Dindayal Upadhyay Dental College, Solapur, Maharashtra, India

${ }^{6}$ Department of Orthodontics, Yashwantrao Chavan Dental College, Ahmednagar, Maharashtra, India

Corresponding Author: Nitin M Lokhande, Department of Conservative Dentistry and Endodontics, SMBT Dental College and Hospital, Sangamner, Maharashtra, India, Phone: +91 7709387538, e-mail:drnlokhande@gmail.com

How to cite this article: Lokhande NM, Manjunath SH, Patil AK, et al. Effect of Different Cavity Disinfectants on Marginal Sealing Ability of a Seventh-generation Dentin Bonding Agent: An In Vitro Study. J Contemp Dent Pract 2020;21(3):242-248.

Source of support: Nil

Conflict of interest: None

solutions such as chlorhexidine, sodium hypochlorite, fluoridebased solutions, hydrogen peroxide, iodine, and benzalkonium chloride were used as cavity disinfectants to eliminate residual bacteria from the prepared cavities. ${ }^{7-11}$

Seventh-generation dentin-bonding agents were introduced in late 2002, which consisted of etchant, primer, and adhesive resin in a single bottle. ${ }^{12}$ The microleakage between the tooth-resin interfaces 
reduced comparatively with seventh-generation dentin-bonding agent as compared to other generations of dentin-bonding agent. It is well known that marginal gap occurs at the tooth restoration junction due to polymerization shrinkage during the setting of composites resin. ${ }^{13}$

However, there is concern regarding sterilization of cavity preparation with disinfecting solutions, since they may change sealing interaction between dentin and hydrophilic resin., ${ }^{3,11}$ In oppose to this, it has also been found that disinfecting solutions remoisten the cavity walls prior to the placement of a dentinbonding agent, thus improving the sealing interaction of the dentin-bonding agents to moist tooth structure. ${ }^{14}$

The aim of this in vitro study is to measure the effect of three different cavity disinfectants (2\% chlorhexidine gluconate, $2.5 \%$ sodium hypochlorite, and $2 \%$ iodine solution) on marginal sealing ability of a seventh-generation dentin-bonding agent.

\section{Materials and Methods}

The present study was conducted at A.C.P.M Dental College, Dhule, Maharashtra, India. Fifty recently extracted (periodontally compromised), noncarious, unrestored human teeth (first permanent mandibular molars) were collected $(n=50)$. All teeth were kept in 3\% sodium hypochlorite solution (Vishal chemical, Nasik) for 10 minutes after scraping the remaining tissues, if any and then rinsed with running tap water for 15 minutes. After cleaning with pumice, they were stored in normal saline at $4^{\circ} \mathrm{C}$ until use.

Class $V$ cavity on both the facial and lingual surfaces of each tooth were prepared using high-speed airotor handpiece, cylindrical diamond bur, and underwater spray coolant (Fig. 1A). The bur was replaced after every four preparations. The cavity dimensions that were approximately $4 \mathrm{~mm}$ long parallel to the cementoenamel junction (CEJ), $1.5 \mathrm{~mm}$ in depth, and $2 \mathrm{~mm}$ in width were used to methodize the cavity preparations. Cavity dimensions were measured and controlled by premarked periodontal probe.

All cavity preparation margins were without bevel with gingival wall placed $1 \mathrm{~mm}$ below the CEJ. Furthermore, all preparations were rinsed with distilled water and subsequently followed by air-drying for 20 seconds.

All cavity preparations were then haphazardly distributed into five groups as listed in Table 1.

Group I-20 cavity preparations with application of $2 \%$ chlorhexidine gluconate solution (Azure Laboratories Pvt., Ltd. Maneed, Kochi, India) proceeded by Adper Easy One (3M ESPE, Germany) application.

Group II-20 cavity preparations with application of $2.5 \%$ sodium hypochlorite solution (Asian Acrylates, Mumbai, India) proceeded by Adper Easy One application.

Group III-20 cavity preparations with application of $2 \%$ iodine disinfecting solution (MP Sai Enterprise, Mumbai, India), proceeded by Adper Easy One application.

Group IV (negative control) - 20 cavity preparations that were without application of any cavity disinfecting solution; however, Adper Easy One was applied.

Group V (positive control)-20 cavity preparations that were treated neither with disinfecting solution nor a dentin-bonding system.

The disinfecting solution was applied for 20 seconds using applicator tips in the respective test groups followed by excess removal with compressed air for 5 seconds.
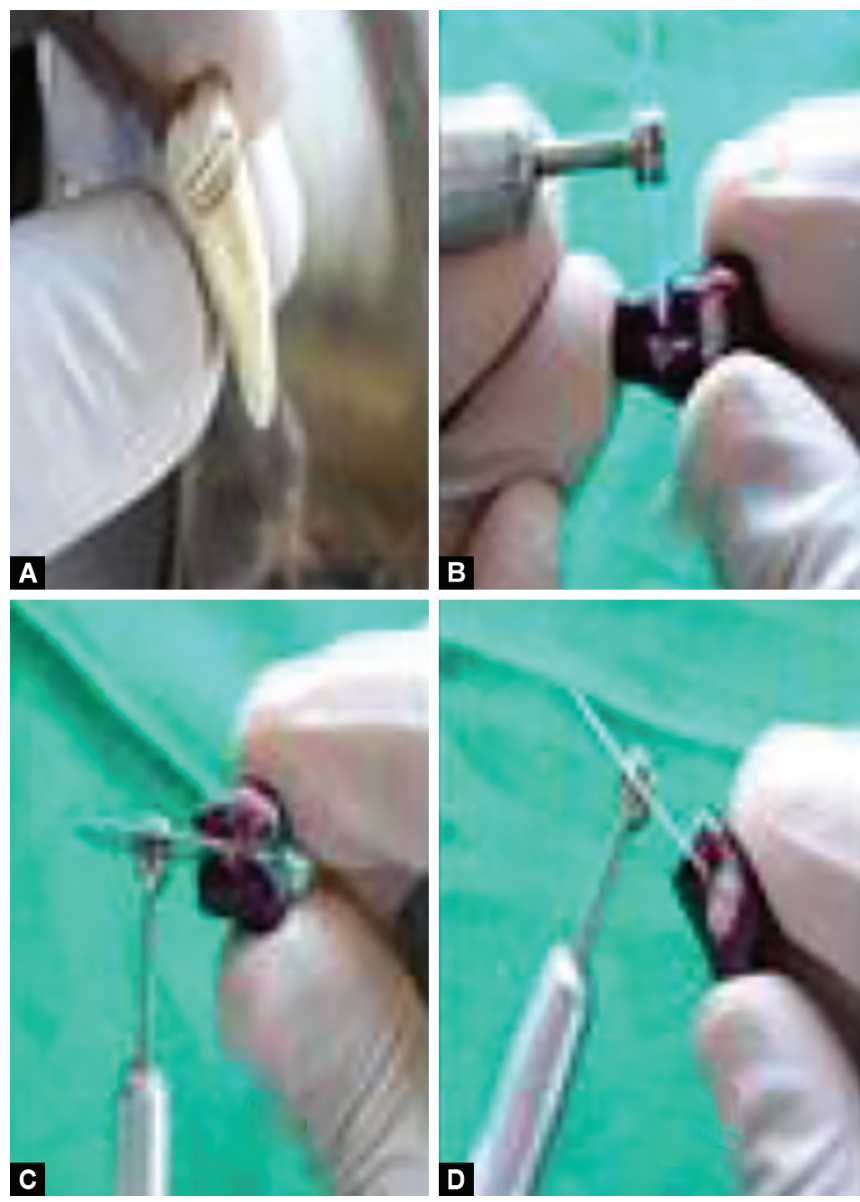

Figs 1 A to D: (A) Class V cavity preparation; (B) Root sectioning; (C) Mesiodistal sectioning; (D) Buccolingual sectioning

Table 1: Experimental groups used in the study

\begin{tabular}{lll}
\hline Groups & Disinfectant treatment & $\begin{array}{l}\text { Dentin-bonding } \\
\text { system (seventh } \\
\text { generation) }\end{array}$ \\
\hline I & $\begin{array}{l}\text { 2\% chlorhexidine gluconate } \\
\text { solution (Azure Laboratories Pvt., } \\
\text { Ltd., Maneed, Kochi, India) }\end{array}$ & \\
II & $\begin{array}{l}\text { 2.5\% sodium hypochlorite solution } \\
\text { (Asian Acrylates, Mumbai, India) }\end{array}$ & $\begin{array}{l}\text { Adper Easy One (3M } \\
\text { ESPE, Germany) }\end{array}$ \\
III & $\begin{array}{l}\text { 2\% iodine solution (MP Sai } \\
\text { Enterprise, Mumbai, India) }\end{array}$ \\
IV & None & \\
$\mathrm{V}^{+}$ & None & None \\
\hline
\end{tabular}

*, negative control; + , positive control

After application of cavity disinfectant, dentin-bonding agent (Adper Easy One) was applied to the appropriate experimental groups following the manufacturer's instructions.

Adhesive was applied with disposable brush applicator tip to all surfaces of the cavity by rubbing it for 20 seconds and light cured for 10 seconds. The cavity preparations were then restored with a resin composite (Filtek ${ }^{\mathrm{TM}} Z$ 350) in increments. The final increment was placed flush with contour of the tooth and covered with a transparent cellulose acetate strip. Each increment was light cured 

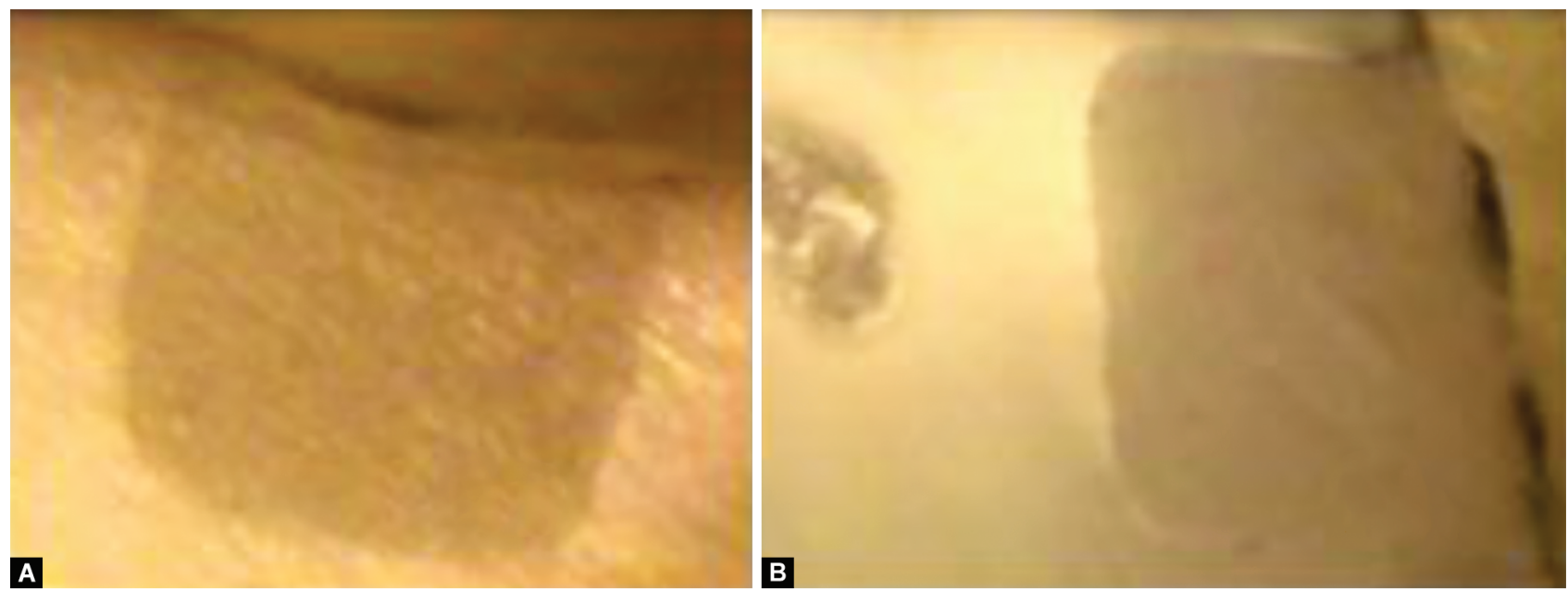

Figs 2A and B: (A) No evidence of dye penetration (score 0) (group IV); (B) Dye penetration less than one half of the length of occlusal/gingival wall (score 1) (group I)

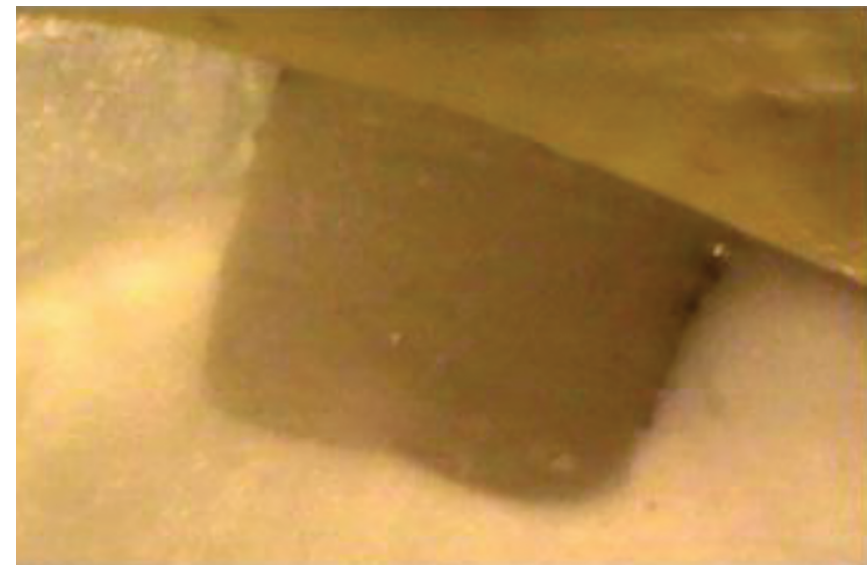

Fig. 3: Dye penetration greater than one half of the length of occlusal/ gingival wall (score 2) (group III)

for 20 seconds. All the restorations were then finished immediately after polymerization using the finishing kit (Shofu Inc., Japan) and sandpaper discs (Microdont, Brazil). Final polishing was carried out with polishing kit using the polishing paste (Shofu Inc., Japan).

Then all the teeth were kept in distilled water at $37^{\circ} \mathrm{C}$ for 24 hours and later processed to 1,000 thermal cycles between water baths of $5^{\circ} \mathrm{C}$ and $55^{\circ} \mathrm{C}$ with a dwell time of 30 seconds. Then the teeth were exposed to dye leakage tests.

The root apices of all the specimens were sealed with modelling wax, and teeth were covered with two coats of nail varnish, leaving $1 \mathrm{~mm}$ of window around the tooth-restoration margin. In separate sealable glass beaker, the specimens were immersed in India ink (HiMedia, Mumbai) for 24 hours at $37^{\circ} \mathrm{C}$. Furthermore, residual stain was cleared away by rinsing with distilled water.

The preparation of radicular parts were accomplished by cutting horizontally $4.5 \mathrm{~mm}$ down to the CEJ (Fig. 1B) and subsequently the coronal parts were prepared by sectioning mesiodistally (Fig. 1C) and then buccolingually (Fig. 1D) in appropriate center of the restoration with diamond disc mounted in mandrill at slow speed.

Both occlusal and gingival margins were examined by two observers for microleakage evaluation under stereomicroscope at $\times 16$ magnification. The dye leakage was assessed according to the following scale:

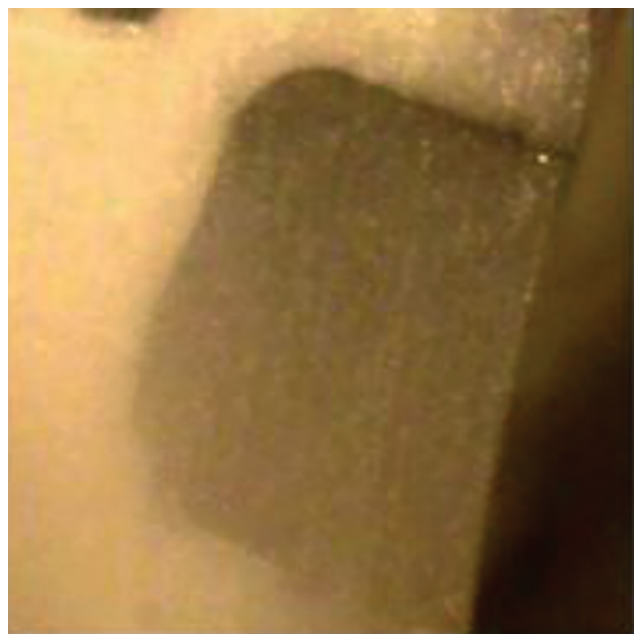

Fig. 4: Dye penetration up to and along the axial wall (score 3) (group II)

(Turkun and Turkun) $^{14}$

Score 0 -no leakage (Fig. 2A)

Score 1-penetration of less than one half of the length of occlusal/gingival wall (Fig. 2B)

Score 2-penetration greater than one half of the length of occlusal/gingival wall (Fig. 3)

Score 3-penetration up to and along the axial wall (Fig. 4)

Score 4-penetration within the pulp (Fig. 5)

\section{Statistical Analysis}

The Mann-Whitney Wilcoxon $U$ test for nonparametric data were used for pairwise comparisons between groups. Statistically significant differences among the groups were determined using a nonparametric ANOVA test (Kruskal-Wallis). Wilcoxon matched pair signed rank test was used to compared the occlusal and gingival margins within the experimental groups. The level of significance was established as $p<0.05$, for all tests.

\section{Results}

In the present study, complete prevention of microleakage was not seen in any group. Microleakage in all groups at the occlusal margins 


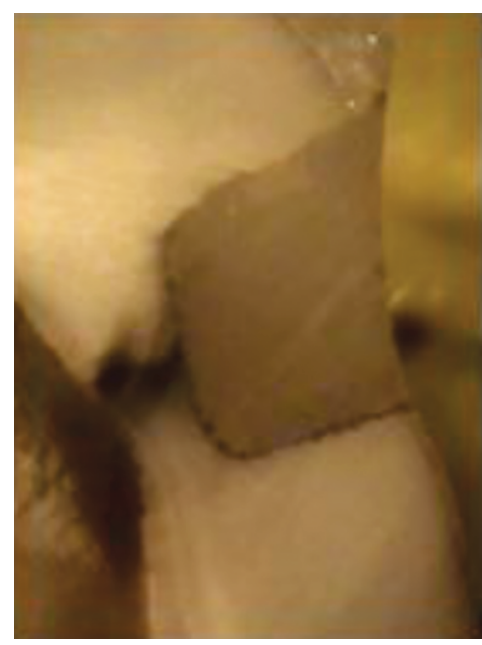

Fig. 5: Dye penetration within the pulp (score 4) (group V)

Table 2: Microleakage scores of the groups at gingival and occlusal margins

\begin{tabular}{llrrrrrr}
\hline & & \multicolumn{7}{c}{ Score } & \\
\cline { 2 - 6 } Groups & Margins & 0 & 1 & 2 & 3 & 4 & Total \\
\hline $\begin{array}{l}\text { Chlorhexidine gluconate } \\
\text { (group I) }\end{array}$ & Gingival & 7 & 5 & 6 & 2 & 0 & 20 \\
& Occlusal & 9 & 6 & 4 & 1 & 0 & 20 \\
$\begin{array}{l}\text { Sodium hypochlorite } \\
\text { (group II) }\end{array}$ & Gingival & 6 & 5 & 5 & 4 & 0 & 20 \\
& Occlusal & 8 & 6 & 3 & 3 & 0 & 20 \\
lodine (group III) & Gingival & 8 & 2 & 7 & 3 & 0 & 20 \\
& Occlusal & 9 & 5 & 4 & 2 & 0 & 20 \\
Negative control & Gingival & 13 & 5 & 2 & 0 & 0 & 20 \\
(group IV) & Occlusal & 16 & 4 & 0 & 0 & 0 & 20 \\
& Gingival & 0 & 0 & 0 & 17 & 3 & 20 \\
Positive control (group V) & Occlusal & 0 & 0 & 3 & 15 & 2 & 20 \\
\hline
\end{tabular}

Table 3: Mean microleakage scores at gingival and occlusal margins of the groups

\begin{tabular}{lllll}
\hline & Margins & $n$ & Mean & $\begin{array}{l}\text { Std. } \\
\text { deviation }\end{array}$ \\
\hline $\begin{array}{l}\text { Groups } \\
\text { (group I) }\end{array}$ & Gingival & 20 & 1.15 & 1.04 \\
& Occlusal & 20 & 0.85 & 0.93 \\
Sodium hypochlorite (group II) & Gingival & 20 & 1.35 & 1.14 \\
& Occlusal & 20 & 1.05 & 1.1 \\
lodine (group III) & Gingival & 20 & 1.25 & 1.16 \\
& Occlusal & 20 & 0.95 & 1.05 \\
Negative control (group IV) & Gingival & 20 & 0.45 & 0.69 \\
& Occlusal & 20 & 0.2 & 0.41 \\
Positive control (group V) & Gingival & 20 & 3.15 & 0.37 \\
& Occlusal & 20 & 2.95 & 0.51 \\
\hline
\end{tabular}

was lower compared to the gingival margins but not statistically significantly different $(p>0.05)$. Highest mean microleakage score was observed in the positive control group (group V: gingival-3.15 \pm 0.37 , occlusal $-2.95 \pm 0.51$ ), whereas the negative control group (group IV: gingival $-0.45 \pm 0.69$, occlusal $-0.2 \pm 0.41$ ) exhibited least
Table 4: Comparison of microleakage scores between the five groups for gingival margins

\begin{tabular}{llll}
\hline & Group & $n$ & Mean rank \\
\hline $\begin{array}{l}\text { Gingival mar- } \\
\text { gins }\end{array}$ & I & 20 & 43.2 \\
& II & 20 & 47.53 \\
& III & 20 & 45.03 \\
& IV & 20 & 29.77 \\
& V & 20 & 86.25 \\
Chi-square & & 46.534 & \\
df & 4 & \\
$p$ value & & $<0.01$ & \\
\hline
\end{tabular}

Statistically highly significant difference $(p<0.01)$

Table 5: Comparison of microleakage scores between the five groups for occlusal margins

\begin{tabular}{llll}
\hline & Group & $n$ & Mean rank \\
\hline Occlusal margins & I & 20 & 43.45 \\
& II & 20 & 47.7 \\
& III & 20 & 45.25 \\
& IV & 20 & 29.65 \\
& V & 20 & 86.45 \\
Kruskal-Wallis test & & Occlusal & \\
Chi-square & & 47.36 & \\
df & & 4 & \\
$p$ value & & $<0.01$ & \\
\hline
\end{tabular}

Statistically highly significant difference $(p<0.01)$

mean microleakage score at occlusal and gingival margins. Among the experimental groups, chlorhexidine gluconate group (group I: gingival-1.15 \pm 1.04 , occlusal-0.85 \pm 0.93 ) exhibited lower mean microleakage score compared to the iodine group (group III: gingival-1.25 \pm 1.16 , occlusal- $0.95 \pm 1.05$ ) which had lower mean microleakage score compared to the sodium hypochlorite group (group Il: gingival-1.35 \pm 1.14 , occlusal-1.05 \pm 1.1 ) at both occlusal and gingival margins.

All experimental groups and negative control group exhibited less microleakage when compared to the positive control group which was statistically highly significant $(p<0.01)$. No statistically significant differences were observed among groups I, II, and III $(p>0.05)$ (Tables 2 to 6, and Fig. 6).

Result showed that $2 \%$ chlorhexidine gluconate exhibited least microleakage compared to $2 \%$ iodine and $2.5 \%$ sodium hypochlorite, similarly occlusal margins exhibited less microleakage than gingival margins:

Chlorhexidine group < iodine < sodium hypochlorite

\section{Discussion}

Adhesive systems are used extensively in clinical practice for bonding to tooth structure. These are used for direct and indirect tooth-colored esthetic restorations, amalgam restorations, and crowns. The current composites are the most promising toothcolored materials in dentistry.

The formation of interfacial gap at the composite resintooth margin may occur due to the polymerization shrinkage of composite resin restoration and this gap results in the passage of ions, fluids, and microorganisms at the tooth-resin interface, a 
Effect of Disinfectants on Sealing Ability of Dentin Bonding Agent

Table 6: Comparison of microleakage scores in-between gingival and occlusal margins within the groups

\begin{tabular}{|c|c|c|c|c|c|}
\hline \multirow{2}{*}{$\frac{\text { Groups }}{\mathrm{I}}$} & \multirow[b]{2}{*}{ Negative ranks } & \multirow{2}{*}{$\frac{n}{8}$} & \multicolumn{2}{|r|}{ Mean rank } & \multirow{2}{*}{$\frac{\text { Sum of ranks }}{44.00}$} \\
\hline & & & & 5.50 & \\
\hline & Positive ranks & 3 & & 7.33 & 22.00 \\
\hline & Ties & 9 & & & \\
\hline & Total & 20 & & & \\
\hline \multirow[t]{4}{*}{ II } & Negative ranks & 7 & & 5.50 & 38.50 \\
\hline & Positive ranks & 3 & & 5.50 & 16.50 \\
\hline & Ties & 10 & & & \\
\hline & Total & 20 & & & \\
\hline \multirow[t]{4}{*}{ III } & Negative ranks & 7 & & 7.50 & 52.50 \\
\hline & Positive ranks & 5 & & 5.10 & 25.50 \\
\hline & Ties & 8 & & & \\
\hline & Total & 20 & & & \\
\hline \multirow[t]{4}{*}{ IV } & Negative ranks & 6 & & 4.67 & 28.00 \\
\hline & Positive ranks & 2 & & 4.0 & 8.00 \\
\hline & Ties & 12 & & & \\
\hline & Total & 20 & & & \\
\hline \multirow[t]{4}{*}{ V } & Negative ranks & 6 & & 4.50 & 27.00 \\
\hline & Positive ranks & 2 & & 4.50 & 9.00 \\
\hline & Ties & 12 & & & \\
\hline & Total & 20 & & & \\
\hline \multicolumn{6}{|l|}{ Test statistics } \\
\hline & Group I & Group II & Group III & Group IV & Group V \\
\hline$Z$ & -0.998 & -1.165 & -1.087 & -1.508 & -1.414 \\
\hline \multirow[t]{2}{*}{$p$ value (two tailed) } & 0.318 & 0.244 & 0.277 & 0.132 & 0.157 \\
\hline & $\begin{array}{l}\text { Not significant } \\
(p>0.05)\end{array}$ & $\begin{array}{l}\text { Not significant } \\
(p>0.05)\end{array}$ & $\begin{array}{l}\text { Not significant } \\
(p>0.05)\end{array}$ & $\begin{array}{l}\text { Not significant } \\
(p>0.05)\end{array}$ & $\begin{array}{l}\text { Not significant } \\
(p>0.05)\end{array}$ \\
\hline
\end{tabular}

No statistically significant difference $(p>0.05)$

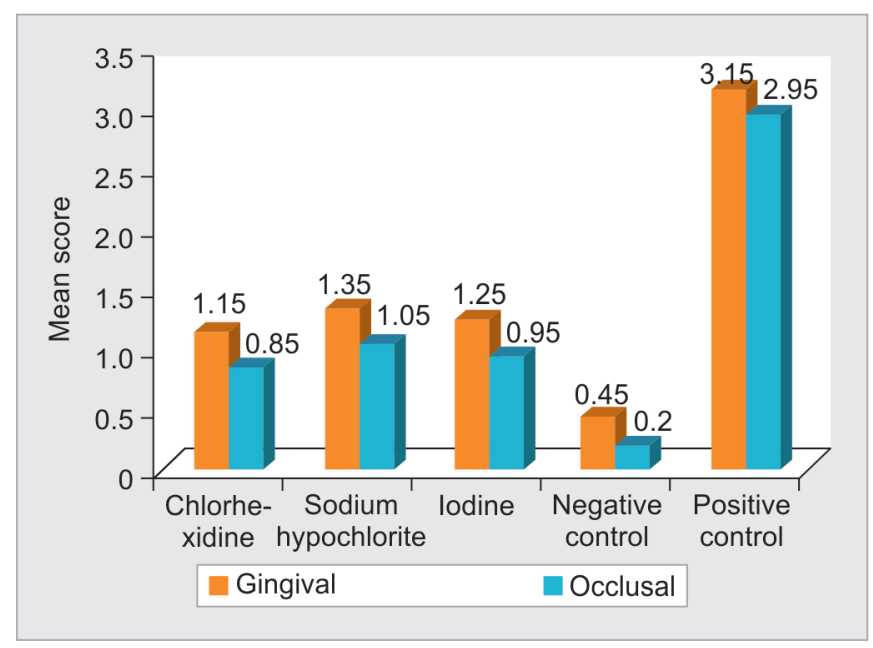

Fig. 6: Mean microleakage scores at gingival and occlusal margins of the groups

process known as microleakage. ${ }^{4}$ Growth of microorganisms under a restoration results in tooth hypersensitivity, weakening of bond strength, development of secondary caries, pulpal inflammation, and necrosis of the pulp. ${ }^{15}$ It is believed that gross disinfection of the cavity preparation before inserting the restorative material is the best that can be achieved to reduce the potential risk of sensitivity and residual caries. ${ }^{16}$
In the last decades, many chemicals have been tested as cavity disinfectants, including chlorhexidine gluconate, benzalkonium chloride, iodine potassium iodide/copper sulfate, fluoride, sodium hypochlorite, etc. ${ }^{16-18}$ The present study was performed to understand the effects of three different cavity disinfecting solutions ( $2 \%$ chlorhexidine gluconate, $2.5 \%$ sodium hypochlorite, and $2 \%$ iodine solution) on the sealing ability of the seventhgeneration dentin-bonding system (Adper Easy One).

Chlorhexidine inactivates microorganisms with a broader spectrum and has a quicker killing rate compared to other antimicrobials. It has both bacteriostatic and bactericidal action, depending on its concentration. ${ }^{19}$

Sodium hypochlorite is another alternative disinfecting agent due to its tissue dissolving properties. It is a nonspecific proteolytic agent that can remove organic materials. The antimicrobial effectiveness of sodium hypochlorite is similar to the mechanism of action of calcium hydroxide due to its high $\mathrm{pH}^{20}$

Many investigators have observed that iodine-potassium iodide solution $\left(\mathrm{I}_{2}-\mathrm{KI}\right)$ can reduce the growth of Streptococcus mutans in pit and fissures having incipient caries lesions as well as on smooth surface..$^{21,22}$ The iodine component of $\mathrm{I}_{2}-\mathrm{KI}$ seems to be the predominant source of antimicrobial activity. ${ }^{23}$

The application of disinfecting solution, after cavity preparation and before application of bonding agents, may help to eliminate the potential risk of postoperative sensitivity and residual caries. However, if cavity disinfectants significantly enhance the extent of 
microleakage, by intervening in the bonding agent's interaction with dentin, any positive benefits would be denied. ${ }^{16}$

Self-etch adhesives are able to create a hybrid layer into the collagen network of dentin by demineralizing the smear layer and underlying dentin along with simultaneous penetration of resin monomers into the demineralized zone, thus improving marginal integrity and relieving patient symptoms.

The bond strength of self-etching adhesives to dentin was found to be almost equal to the total-etch adhesives. ${ }^{24}$ Adper Easy One is a seventh-generation, single-component, no-mix, one-step application dental adhesive with an etchant, adhesive, desensitizer, and photoinitiator. Adper Easy One showed the highest tensile bond strength. ${ }^{25}$

The presence of statistically significant difference between the negative control and experimental group I treated with $2 \%$ chlorhexidine gluconate showed that $2 \%$ chlorhexidine gluconate adversely affected the sealing abilities of dentin-bonding system. This finding is in accordance with the studies conducted by Tulunoglu et al., ${ }^{26} \mathrm{Pin}^{27}$ Singla et al., ${ }^{28}$ and Agrawal et al. ${ }^{29}$

The $\mathrm{pH}$ of self-etching adhesives is comparatively higher than the phosphoric acid etchants. Meiers and Kresin found that in scanning electron microscopic examination, chlorhexidine cavity disinfectant was resistant to acid conditioning. ${ }^{3}$ This acidresistant layer might restrain the weak acidic primers to efficiently demineralize the dentin and impede penetration of hydrophilic resin into the dentin surface. ${ }^{28}$

In contrary to the result of the present study, Turkun et al. ${ }^{14}$ and Sharma et al. ${ }^{16}$ found that chlorhexidine-based cavity disinfectant did not increase microleakage when used with Prompt L-Pop (selfetching adhesive) and Clearfil SE bond (self-etching primer).

The difference in the results may be attributed to the use of acid etching and different chemical composition of dentin-bonding agents. Darabi et al. ${ }^{30}$ evaluated the effect of chlorhexidine-based cavity disinfectant on microleakage using different dentin-bonding systems. It was concluded that the sealing ability of dentin-bonding system seems to be inhibited by the remnants of the disinfecting agent, and rinsing off the cavity disinfectant before the bonding procedure did not affect the seal at resin-tooth interface. ${ }^{30}$ In present study, rinsing off the cavity disinfectant was not done.

Group II (2.5\% sodium hypochlorite) showed statistically significant differences in microleakage scores when compared with the negative control group. This finding is in accordance with other studies conducted by Frankenberger et al.,18 Bansal and Tewari, ${ }^{31}$ Ercan et al., ${ }^{11}$ Mirzaei et al., ${ }^{32}$ Pattanaik and Chandak, ${ }^{33}$ and Reddy et al. ${ }^{15}$ Study by Lai et al. suggested greater microleakage and poor adaptation of resin to dentin surface with different adhesive system after sodium hypochlorite treatment could be associated with the oxidizing effect of sodium hypochlorite and its reaction by-products, thus causing interruption in the interfacial polymerization of adhesives. The premature chain termination and incomplete polymerization of adhesives could be related to residual reactive free radicals in dentin with sodium hypochlorite treatment reacting with propagating free vinyl radicals generated during light activation of the adhesive resin, leading to increased microleakage. ${ }^{34}$

Contrary to this study, Agrawal et al. ${ }^{35}$ found reduced microleakage after pretreatment with sodium hypochlorite when used with self-etch adhesive. In their study, they used EDTA before the treatment with sodium hypochlorite and did rinse off the cavity disinfectant. The difference in results could be due to the change in material and method.
Group III showed statistically significant differences when compared with negative control and positive control groups. The result of present study is in accordance with the other studies conducted by Meiers and Kresin, ${ }^{3}$ Turkun et al., ${ }^{14}$ Da Silva et al., and Sharma et al. ${ }^{16}$ Scanning electron microscopic examination showed that $\mathrm{I}_{2}-\mathrm{KI} /$ copper sulfate solution led to the formation of interfacial gap at the composite-tooth junction, regardless of the dentin-bonding system used, and the resin tag was not formed. ${ }^{14}$

This may be based on the fact that leftover residues of $\mathrm{I}_{2}-\mathrm{KI}$ may have decreased the wetting ability of adhesive, subsequently resulting in less impregnation into the dentin surface. $3,7,14$

Contrary to this study, Bansal and Tewari ${ }^{31}$ found significantly less microleakage after $5 \% \mathrm{w} / \mathrm{v}$ povidone-iodine treatment with Xeno III (self-etch adhesive). The difference in results could be attributed to the disinfectants were rinsed off before bonding and different chemical compositions of the bonding agents compared to the present study.

Among the experimental groups, chlorhexidine gluconate group exhibited lower microleakage, and sodium hypochlorite group showed higher microleakage at both occlusal and gingival margins but no statistically significant difference was observed in microleakage scores. lodine group exhibited microleakage to a lesser extent compared to the sodium hypochlorite group but higher than the chlorhexidine group, but it was not significant.

It was also found that gingival margins showed greater microleakage than occlusal margins for all groups but differences were not statistically significant. This finding is in accordance with the studies by Pin, ${ }^{27}$ Xiong et al., ${ }^{36}$ and Sharma et al. ${ }^{16}$

Typically, the cervical margins of class $\mathrm{V}$ restorations are not located in enamel. The margins of these preparations are not conducive to acid etching and dentin bonding and thus do not improve marginal seal. ${ }^{37}$

This was an in vitro study and the results may not necessarily be the same as those that would be obtained in the oral environment. In extracted teeth, dentinal collagen fibrillar network may collapse and thus exhibit inadequate impregnation into dentin surface. So further long-term clinical studies are required to evaluate the efficacy and effect of cavity disinfectants on the sealing ability of dentin-bonding system.

\section{Conclusion}

All tested disinfectants, i.e., $2 \%$ chlorhexidine gluconate, $2.5 \%$ sodium hypochlorite, and $2 \%$ iodine produced significantly higher microleakage when used with the seventh-generation dentin-bonding agent (Adper Easy One). They adversely affected the sealing ability of Adper Easy One. Two percent chlorhexidine gluconate produced microleakage to a lesser extent compared to $2.5 \%$ sodium hypochlorite and $2 \%$ iodine. The gingival margins exhibited greater microleakage than the occlusal margins.

\section{References}

1. Sikri VK. Microleakage. In: Textbook of Operative Dentistry, ch. 23. CBS Publishers; 2006. p. 549.

2. Walshaw PR, McComb D. SEM evaluation of the resin dentin interface with proprietary bonding agents in human subjects. J Dent Res 1994;73(5):1079-1087. DOI: 10.1177/00220345940730051001.

3. Meiers JC, Kresin JC. Cavity disinfectants and dentin bonding. Oper Dent 1996;21(4):153-159. 
4. Brannstrom $M$. The cause of postoperative sensitivity and its prevention. J Endod 1986;12(10):475-481. DOI: 10.1016/S00992399(86)80202-3.

5. Baum L, Phillip RW, Lund MR. Liners and cements. In: Text Book of Operative Dentistry. Harcourt Brace \& Company Asia Pte Ltd, ch. 6; 1997. pp. 132-133.

6. Shafiei F, Memarpour M. Antibacterial activity in adhesive Dentistry: a literature review. Gen Dent 2012;60(6):346-356.

7. Da Silva NR, Calamia CS, Coelho PG. The effect of $2 \%$ iodine disinfecting solution on bond strength to dentin. J Appl Oral Sci 2006;14(6):399-404. DOI: 10.1590/S1678-77572006000600003.

8. Turkun M, Ozata F, Uzer E, et al. Antimicrobial substantivity of cavity disinfectants. Gen Dent 2005;53(3):182-186.

9. Ersin NK, Uzel A, Aykut A, et al. Inhibition of cultivable bacteria by chlorhexidine treatment of dentin lesions treated with the ART technique. Caries Res 2006;40(2):172-177. DOI: 10.1159/000091120.

10. Brannstrom M, Nordenvall KJ, Glantz PO. The effect of EDTA containing surface active solutions on the morphology of prepared dentin: An in vivo study. J Dent Res 1980;59(7):1127-1131. DOI: 10.1177/00220345800590070501.

11. Ercan E, Erdemir A, Zorba YO, et al. Effect of different cavity disinfectants on shear bond strength of composite resin to dentin. J Adhes Dent 2009;11(5):343-346.

12. Chandki R, Kala M. Total etch vs self-etch: still a controversy in the science of bonding. Aosr 2011;1(1):38-42.

13. Fruits $T J$, Knapp JA, Khajota SS. Microleakage in proximal walls of direct and indirect posterior resin slot restorations. Oper Dent. 2006;31(6):719-727. DOI: 10.2341/05-148.

14. Turkun $M$, Turkun $L S$, Kalender A. Effect of cavity disinfectants on the sealing ability of non-rinsing dentin bonding resin. Quintessence Int 2004;35(6):469-476.

15. Reddy MS, Mahesh MC, Bhandary S, et al. Evaluation of effect of different cavity disinfectants on shear bond strength of composite resin to dentin using two-step self-etch and one-step self-etch bonding systems: A comparative in vitro study. J Contemp Dent Pract 2013;14(2):275-280. DOI: 10.5005/jp-journals-10024-1313.

16. Sharma V, Nainan MT, Shivanna V. The effects of cavity disinfectants on the sealing ability of dentin bonding system: An in vitro study. J Conser Dent 2009;12(3):109-113.

17. Brannstrom $\mathrm{M}$, Nyborg $\mathrm{H}$. Cavity treatment with a microbicidal fluoride solution: Growth of bacteria and effect on the pulp.J Prosthet Dent 1973;30(3):303-310. DOI: 10.1016/0022-3913(73)90187-X.

18. Frankenberger $\mathrm{R}$, Krämer $\mathrm{N}$, Oberschachtsiek $\mathrm{H}$, et al. Dentin bond strength and marginal adaption after $\mathrm{NaOCl}$ pre-treatment. Oper Dent 2000;25(1):40-45.

19. Matthijs S, Adriaens PA. Chlorhexidine varnishes: a review. J ClinPeriodontol 2002;29(1):1-8.

20. Estrela C, Estrela CR, Barbin EL, et al. Mechanism of action of sodium hypochlorite. Braz Dent J 2002;13(2):113-117. DOI: 10.1590/S010364402002000200007.

21. Caufield PW, Gibbons RJ. Suppression of streptococcus mutans in the mouths of human by a dental prophylaxis and topically applied iodine. JDent Res 1979;58(4):1317-1326. DOI: 10.1177/00220345790580040301.
22. Meiers JC, Schachtele CF. The effectof antimicrobial solution on the microflora of human incipient fissure caries. J Dent Res 1984;63(1): 47-51. DOI: 10.1177/00220345840630011101.

23. Apostolov K. The effects of iodine on biological activities of myxoviruses. J Hyg 1980;84(3):381-388. DOI: 10.1017/ S0022172400026905.

24. Toledano M, Osorio R, Ceballos L, et al. Microtensile bond strength of several adhesive systems to different dentin depths. Am J Dent 2003;16(5):292-298.

25. Nikhil V, Singh V, Chaudhry S. Comparative evaluation of bond strength of three contemporary self-etch adhesives: an ex vivo study. Contemp Clin Dent 2011;2(2):94-97. DOI: 10.4103/0976-237X. 83068.

26. Tulunoglu $\mathrm{O}$, Ayhan $\mathrm{H}, \mathrm{Olmez} \mathrm{A}$, et al. The effect of cavity disinfectant on microleakage in dentin bonding systems. J ClinPediatr Dent 1998;22(4):299-305.

27. Pin $\mathrm{CH}$. The influence of cavity disinfectants on the microleakage of posterior composite. Seminar penyelidikan Jangka Pendek 2003(VotF): $1-4$.

28. Singla M, Aggarwal V, Kumar N. Effect of chlorhexidine cavity disinfection on microleakage in cavities restored with composite using a self-etching single bottle adhesive. J Conserv dent 2011;14(4):374-377. DOI: 10.4103/0972-0707.87201.

29. Agrawal N, Agrawal H, Patel P. Effect of cavity disinfection with chlorhexidine on microleakage of composite restorations using total etch and self-etch single bottle adhesive systems: an in-vitro study. International J of Healthcare \& Biomedical Research 2013;2:43-47.

30. Darabi F, Eftekhari M. Effect of chlorhexidine on microleakage of composite restorations. J Dent Tehran 2009;6(1):16-22.

31. Bansal S, Tewari S. Ex vivo evaluation of dye penetration associated with various dentin bonding agents in conjunction with different irrigation solutions used within the pulp chamber. Int Endod J 2008;41(11):950-957. DOI: 10.1111/j.1365-2591.2008.01456.x.

32. Mirzaei M, Kermanshah H, Yassini $E$, et al. Influence of sodium hypochlorite on microleakage of three-step total-etch bonding agent with different solvents. IRAN (JIDA) 2013;25:53-60.

33. Pattanaik N, Chandak M. The effect of three cavity disinfectants (chlorhexidine gluconate-based. Consepsis; Benzalkonium chloritebased, Tubulicid red; Sodium hypochlorite based-Chlorcid V on the self-etch dentine bonding agent (Adeper easy one, 3M ESPE) under SEM. IOSR J Dent Med Sci 2013;8:84-89.

34. Lai SCN, Mak YF, Toledano M. Reversal of compromised bonding to oxidized etched dentine. J Dent Res 2001;80(10):1919-1924. DOI: 10.1177/00220345010800101101.

35. Agrawal R, Tyagi SP, Nagpal R, et al. Effect of different root canal irrigants on the sealing ability of two all-in-one self-etch adhesives: an in vitro study. J Conserv Dent 2012;15(4):377-382. DOI: 10.4103/09720707.101917.

36. Xiong $\mathrm{Y}$, Chen $\mathrm{J}-\mathrm{H}$, Wang $\mathrm{H}$, et al. Evaluation of shear bond strength and microleakage of deproteinized dentin bonded with three totalsetch adhesive system. Int Chin J Dent 2006;6:82-88.

37. Bauer JG, Henson JL. Microleakage: a measure of the performance of direct filling materials. Oper Dent 1984;9(1):2-9. 